\title{
106. 人耳下腺の電子顕微鏡的研究
}

$\begin{array}{cccc}\text { 。清 水 } & \text { 天・北 村 } & \text { 武 } \\ \text { 神 田 } & \text { 敬・今 野 昭 } & \text { 義 }\end{array}$

\section{研 究目的}

動物を用いた睡液腺の電子顕微鏡的研究は，数多く 発表されているが，人耳下腺の電子顥溦鏡的研究は, $2 \sim 3$ の報告を見るにすぎない．まして病的耳下腺の 電子顕微鏡的研究は，全然報告を見ないようである。 幸い当教室は多くの耳下腺疾患の症例に恵まれている ので，耳下腺病理組織を電子顕微鏡的に観察し，その 一部哽液管拡張症の所見を正常人耳下腺電影像之対比 して報告した。

梅液管拡張症は，四影法 (Sialographie) の所見か ら初めて命名された疾㭧で，10才以下の小児に初発す るととが多く，耳下腺の腄脹を反復し，急性增要期に

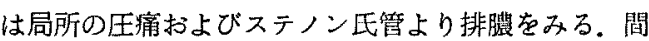
歇期には，口内乾燥感・睡液隇少を訴える以外には， 何ら症状を示さないととが多い，渪影像では，腺葉部

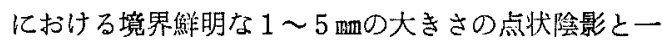
部に脽管系の拡張を認める。

\section{材料および方法}

正常耳下腺組織を，耳下腺および頭頸部手術 (36例) の際, 棰液管拡張症 (12例) およびその治瘾例（4例） の組織を切除した。試料は直ちに $1 \sim 2 \mathrm{~mm}$ 角に細切後, S-collidine あるいは燐酸緩衙 1 ～2\%オスミウム酸 にて 1 時間固定, またはグルタールアルデヒドにて 2 時間前固定後，オスミウム酸にて 1 時間後固定を行な い, アルコールで脱水し, Luft の方法によつて, Epon 812 に包埋した. Porter-Blum の超ミクロト 一ムで超薄切片を作斵し，酢酸ウラニールと，Mllonig, Reynolds の鉛塩との二重染色を行ない，日 立 HS 7 型電子顕微鏡で撮影した。また試料の一部を ホルマリン固定, パラフイン包理, ヘマトキシリンエ オシン重染色, PAS 染色を行ない，光学顕微鏡にて 観察した。 なおEpon包埋の組織も，1 $1 \mu$ 切片を作製 し，トルイジンブルー染色，または塩基性フクシンと メチレンブルーの重染色を行ない，光学顕微鏡的に対 比検索した。
(1) 光学顕微鏡的所見

本症では小葉内に管上皮に由来すると思われる 2 3 尿の上皮で被われた直经 $1 \sim 3 \mathrm{~mm}$ の大きな搪張腔が 存在するが，てれはレントゲンの点状陰影に相当する むのと思われる、今回演者は，本症の耳下腺生検材料 の微細構造を検索したところ，レントゲン像ての点状 陰影以外の部分, すなわち拡張腔周辺の終末部, 介在

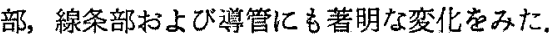

(2) 電子顕微鏡的可見

終末部では腺院が不規則に拡張していろ. 拡張の程 度は，臨床症状の重いちの程強いが，また同じ症例で も拡張の㺈い部分之，弱い部分がある，拡張の強い部 分では，腺腔が基底膜の近くまで拡がり，核が基底部 へ压迫されている．腺腔には microvilli がほとんど 見られない，紐胞間分泌毛細管も拡㖘しており， $\mathrm{mi}$ crovilli は減少している，また，腙腔と細胞間分泌毛 紐管が繁合して，一つの大きな腔となり，さらに近く の分汼毛紐管と撚合して，もつと大きな腔となる㑯向 が見られた。 また介在部，線条部においても腺沿の拉 張は著しく，抆張した腺腔内に，しばしば白血球・リ ンパ球などを訫めた。

つぎに本症の際には3 種類の分必顆粒が見られた. 1 つは電子密度の低い均一心分泌顆粒で，乙れは正常耳 下腺に見られる分泌顆粒と同しである，2番目に多く みられる分泌顆粒は非常に電子密度の高い顆粒である。 3 番目はまれにしかみられない分泌顆粒だが，比較的 電子密度の低い分泌顆粒の形歵内に簐子密度の高い小 体を1〜2 個含有している. この顆粒は PAS 染色. アルシアンプルー染色で陽性に染まる．本症の際には 分泌顆粒の数は正常之較へて減少している. 粗面小胞 体, ゴルジー装置, 糸粒体などの細胞内小器官も本症 の際には減少している。つぎ導管も本应の際には著 明に拡張している。臨床症状の強い症例では，導管上 皮が重自屏平上皮へ化生を起ししているのがみられた。 
また間篔にはリンパ球・白血球・形賀細胞などの曼潤 が著しく，翏原線維・線維芽細胞の增殖もみられた， なお本症の前歴があるが，最近 5 年以上耳下腺の婳脹 を起こさないすなわち臨床的治㾌の状態にある应例も あわせ観察したが, 腺腔の拡張, 分泌顆粒の減少, 導 管上皮の扁平上皮化生が依然として認められた。

\section{結論}

（1）小葉内に管上皮に由来すると思われる $2 \sim 3$ 層 の円柱上皮で被われた大きな拡張攻が存在し，その周 囲にリンパ組織の増殖がみられた。この拡張腔は、レ ントゲンの点状陰影と一致するるのと思われる.

（2）終末部は変性, 萎縮を示している.
（3）残存せる䅂末部・介在部・線条部の腺䏶は著し く拡張しており, microvilli が減少している。

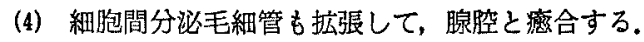

（5）本症の際には 3 種類の分泌顆粒が認められた。 分泌顆粒は一般に減少する。

（6）導管も抆張しており，ときに学管上皮の扁平上 皮化生が見られた。

（7）間䆩には，リンパ・白血球・形質紐胞らの浸潤 が強い。

（8）一度本症に罹患したものは，永い間耳下腺の腫 脹を起てさずまたた自覚庭状なく経過しても，組織像 は正常の状態へ戻らない。 